\title{
Pelatihan E-Learning Menggunakan Office 365 Bagi Guru-Guru dan Siswa-Siswa Madrasah Aliyah Negeri 1 Semarang
}

\author{
Sri Handayani ${ }^{1}$, Saiful Hadi ${ }^{2}$ \\ Universitas Semarang, Jl. Soekarno Hatta, Tlogosari Kulon, Kec. Pedurungan, Kota Semarang, Jawa \\ Tengah 59160 \\ Email: sri@usm.ac.id*
}

\begin{abstract}
ABSTRAK
Madrasah Aliyah Negeri (MAN) 1 Semarang merupakan salah satu Madrasah Aliyah Negeri yang ada di provinsi Jawa Tengah. MAN 1 Semarang merupakan salah satu sekolah swasta di kota Semarang yang selalu memperbaharui pembelajaran dengan menerapkan teknologi terkini. Salah satu teknologi yang ingin diterapkan saat ini adalah mengoperasikan Microsoft Office 365 sebagai salah satu media yang akan mendukung pelaksanaan pembelajaran. Tim Pengabdian kepada Masyarakat (PkM) dari Fakutas Teknologi Informasi dan Komunikasi (FTIK) Universitas Semarang (USM) telah membantu mengenalkan dan memberi pelatihan tentang Microsoft Office 365 pada guru dan siswa-siswi MAN 1 Semarang. Hasil dari pelatihan ini bukan hanya diharapkan menjadi tambahan pengetahuan namun juga dapat menunjang proses pembelajaran yang ada di MAN 1 Semarang.
\end{abstract}

Kata kunci: MAN 1 Semarang; Microsoft Office 365; Pembelajaran.

\section{ABSTRACT}

Madrasah Aliyah Negeri (MAN) 1 Semarang is one of the Madrasah Aliyah Negeri in Central Java province. MAN 1 Semarang is one of the private schools in the city of Semarang that always updates learning by applying the latest technology. One technology that wants to be applied now is to operate Microsoft Office 365 as one of the media that will support the implementation of learning. The Dedication Team from the University of Semarang (USM) Information and Communication Technology Faculty (FTIK) has helped introduce and provide training on Microsoft Office 365 to teachers and students of MAN 1 Semarang. The results of this training are not only expected to be additional knowledge but also can support the learning process in MAN 1 Semarang.

Keywords: MAN 1 Semarang; Microsoft Office 365; Learning.

\section{PENDAHULUAN}

Saat ini dipimpin oleh Drs. H. Kasnawi, MAg. MAN 1 Kota Semarang berusaha untuk mengadakan perubahan baik pada hal manajemen pembelajaran dan sarana prasarana untuk menjadi Madrasah yang berstandar Nasional, salah satunya dengan pembaharuan materi pembelajaran salah satunya yang diselenggarakan di laboratorium Komputer. Laboratorium Komputer adalah tempat riset ilmiah, eksperimen, pengukuran ataupun pelatihan ilmiah yang berhubungan dengan ilmu komputer salah satunya pembelajaran tentang Microsoft Office. 
Selama ini siswa-siswi MAN 1 Semarang telah dikenalkan dan dilatih untuk menggunakan Microsoft Office 2019. Keahlian menngoperasikan Microsoft Office bagi siswa-siswa MAN 1 Semarang mutlak dibutuhkan untuk kebutuhan penyajian tugas yang terkomputersasi dari guru mata pelajaran.

Seiring dengan perkembangan teknologi, saat ini telah dirilis Microsoft Office 365 yang memiliki beberapa kelebihan dibanding Microsoft Office 2019, dan USM telah melakukan kerjasama dengan Microsoft untuk mensuport proses pembelajaran di lingkungan kampus USM salah satunya adalah dengan berlangganan Microsoft Imagine Academy (MIA) sehingga USM mendapat lisensi untuk menyelenggarakan test atau exam sertifikasi di kampus USM.

Sebagai bentuk kepedulian USM pada lingkungan di sekitar, tim PkM ingin berkontribusi mendukung peningkatan proses belajar mengajar di MAN 1 Semarang, karena sekolah ini secara geografis letaknya tidak jauh dari kampus USM, dan banyak lulusan MAN 1 Semarang yang akhirnya berkuliah di USM. Karena telah adanya jalinan relasi yang baik sejak dulu, maka tim PkM FTIK USM sangat antusias membantu proses peningkatan pembelajaran di MAN 1 Semarang akan memberikan account 365 gratis kepada peserta pelatihan (guru-guru dan siswa-siswa). Selain itu tim PkM FTIK USM pun berkeinginan untuk memberikan pengetahuan dan pelatihan dalam menggunakan Office 365.

\section{METODE}

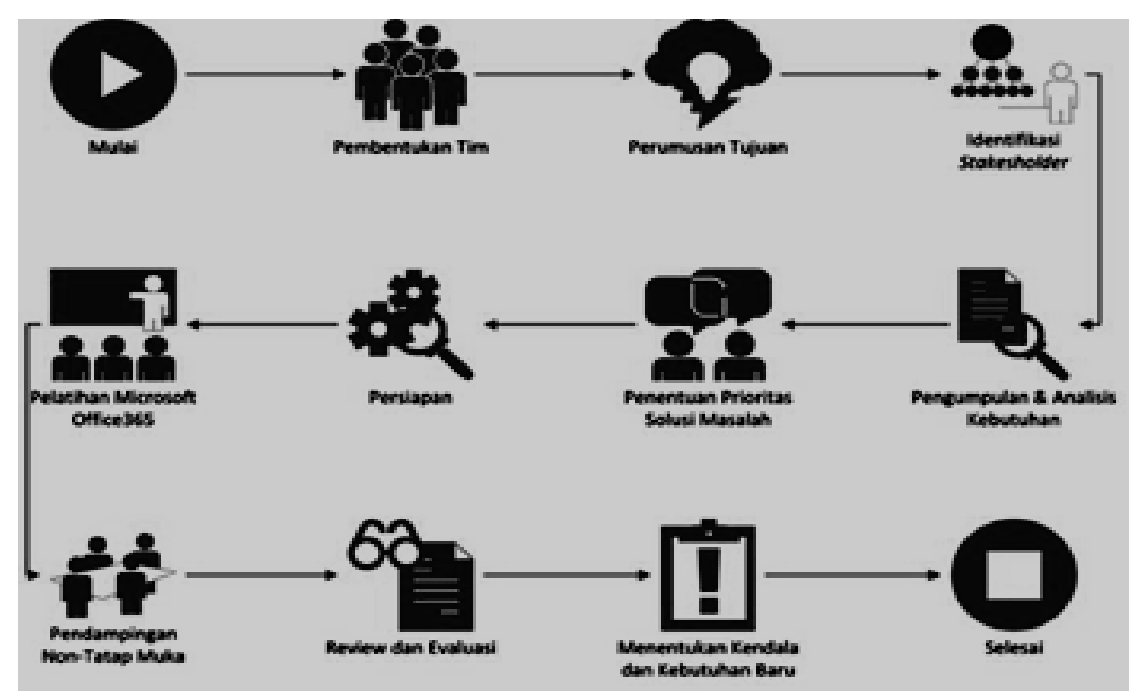

Gambar 1. Metode Pelaksanaan Kegiatan PKM

Pada Gambar 1, menggambarkan proses yang harus dilalui tim PKM FTIK USM untuk melakukan kegiatan pelatihan ini adalah setelah proposal kegiatan Pengabdian kepada Masyarakat disetujui oleh LPPM USM, tim PkM lalu mempersiapkan perijinan yang dibutuhkan untuk pelaksanaan kegiatan di MAN 1 Semarang. Alasan pemilihan peserta 
pelatihan adalah guru-guru dan siswa-siswi MAN 1 Semarang adalah karena banyak mahasiswa Teknik Informatika USM berasal dari lulusan MAN 1 Semarang, sehingga jalinan kerjasama yang ada antara MAN 1 Semarang dengan USM telah terjalin dengan baik. Tim PkM pun bersepakat menganalisa apa saja yang sedang dibutuhkan MAN 1 Semarang dalam proses belajar mengajar. Ternyata MAN 1 Semarang membutuhkan sarana pembelajaran terkini tentang Microsoft Office 365.

Metode yang digunakan dalam kegiatan pengenalan dan pembelajaran Microsoft Office 365 akan diberikan dalam bentuk pelatihan penggunaan komputer untuk mengoperasikan One Note, Sway, Team dari aplikasi Microsoft office 365 secara langsung karena metode ini memiliki presentase tingkat pengaruh yang sangat signifikan terhadap penyerapan materi dan keterampilan berpikir kritis peserta mencapai 77,28\% (Kurniawati et al, 2015).

Untuk tempat Pengabdian kepada Masyarakat ini berada di Kelurahan Pedurungan Kidul Semarang berlangsung selama 4 (empat) sampai 5 (lima) jam selama 2 hari berturutturut dan dan waktu pelaksanaan Pengabdian kepada Masyarakat ini akan diselenggarakan pada tanggal 6-7 Desember 2019.

\section{HASIL, PEMBAHASAN, DAN DAMPAK}

\section{Hasil}

Kegiatan Pengabdian Kepada Masyarakat ini mengambil tema : Pengenalan dan Pembelajaran Microsoft Office 365", diselenggarakan selama 2 (dua) hari yaitu tanggal : 6 dan 7 Desember 2019 bertempat di laboratorium komputer MAN 1 Semarang, Jl. Brigjen Sudiarto Pedurungan Semarang diikuti oleh sebanyak 70 orang guru MAN 1 dan 38 siswa MAN 1 (daftar peserta terlampir). Hari pertama tanggal 6 Desember 2019 pelatihan diperuntukan untuk siswa kelas XI tampak pada gambar 2. pelatihan dimulai pukul : 7.00 WIB dan berakhir pukul : $11.00 \mathrm{WIB}$.

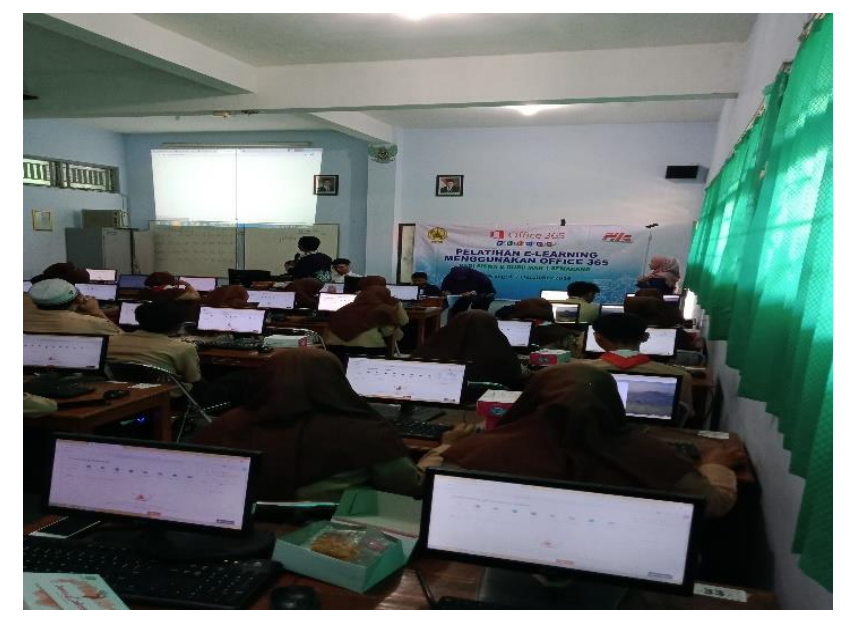

Gambar 2. Pelatihan hari pertama 
Pada hari pertama pelatihan, peserta telah memasuki laboratorium jam 7.00 WIB, tim pelaksana didampingi guru memperkenalkan diri pada peserta pelatihan, siswa kelas XI MAN 1 Semarang. Tim Pengabdian dibantu oleh 4 orang mahasiswa Program Studi Teknik Informatika dan Sistem Informasi USM dalam melakukan kegiatan. Setelah memperkenalkan diri, tim pelaksana mulai melakukan kegiatan pelatihan dengan membagikan kuesioner pre test yang wajib diisi oleh peserta pelatihan, sambil melakukan registrasi bagi peserta.

Setelah materi tersampaikan, tim pengabdian memberikan penugasan pada peserta untuk mengetahui kemampuan peserta pelatihan menyerap materi yang disampaikan. Untuk memotivasi peserta mengerjakan tugas sebaik mungkin, tim pengabdian telah menyediakan reward bagi 3 peserta pelatihan yang tugasnya dinilai paling baik. Tugas yang diberikan adalah tentang sway, peserta pelatihan wajib membuat artikel dalam aplikasi sway yang bertema tentang MAN 1 Semarang. Pada gambar 3 tampak salah satu hasil tugas yang dikerjakan oleh peserta pelatihan.

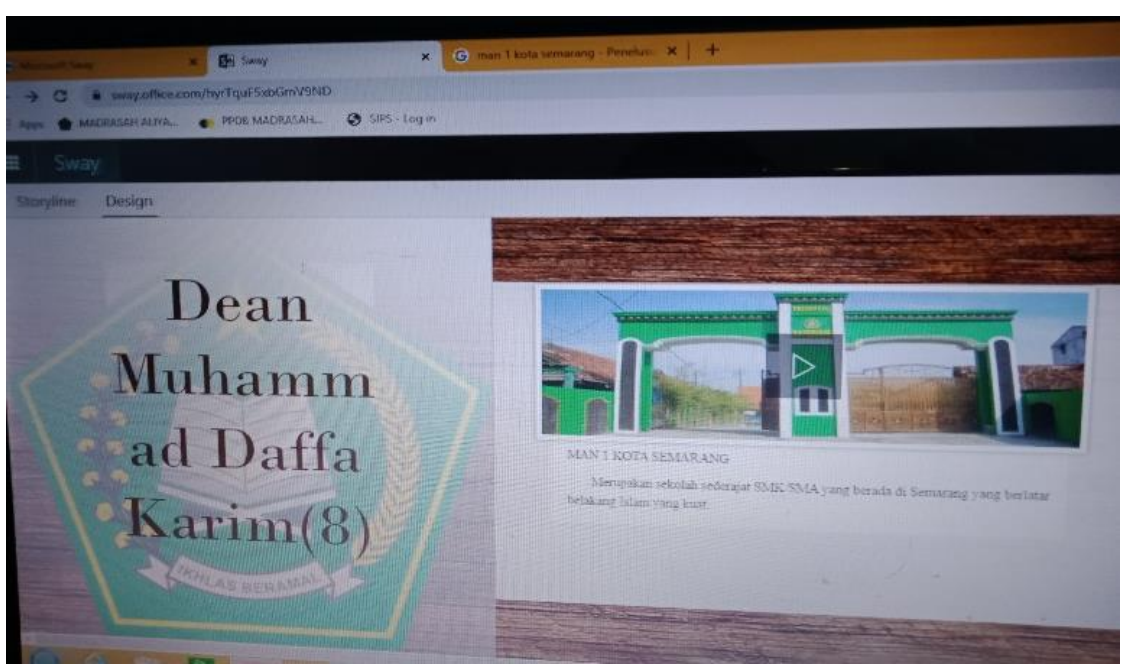

Gambar 3. Hasil Tugas Sway salah satu peserta siswa

Dari hasil penilaian tim pengabdian terhadap tugas-tugas peserta pelatihan terpilih 3 tugas terbaik dan berhak mendapat reward yaitu : Ardiansyah, Alfi Amaliya, dan Azalea. 


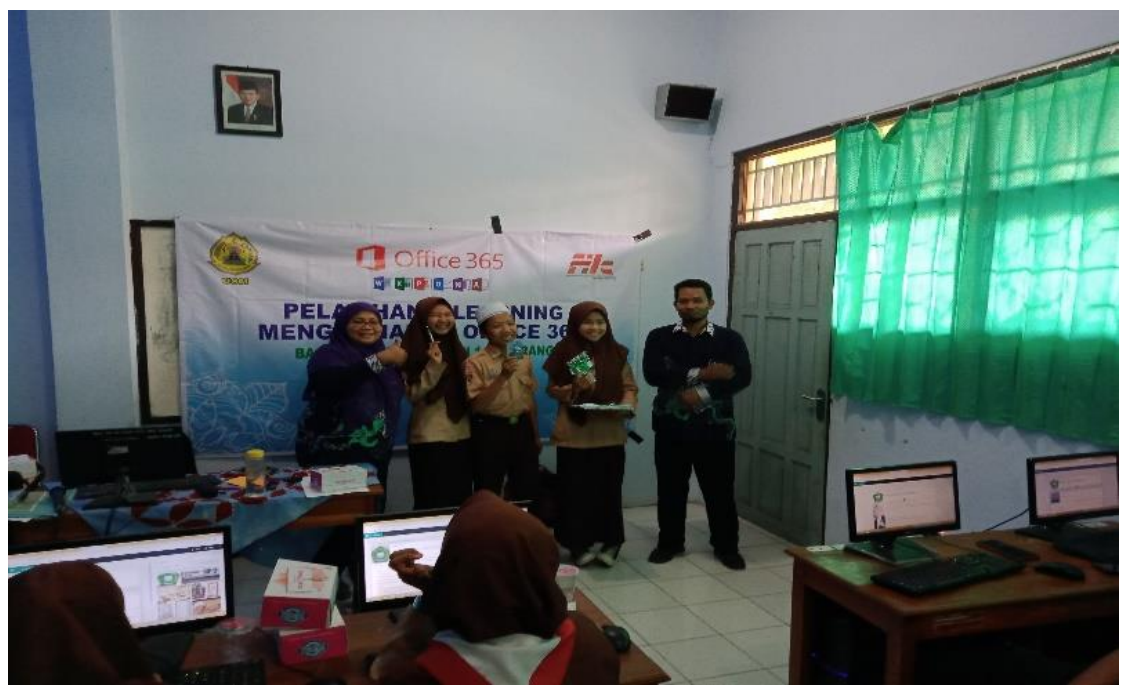

Gambar 4. Foto bersama penerima reward

Reward yang didapatkan berupa pulsa dan cindera mata dari tim pengabdian berupa alat tulis. Pada gambar 4. tampak foto dari 3 siswa yang berhasil mendapatkan reward dari tim pengabdian. Dan pada gambar 5, adalah bukti transfer pulsa bagi 3 siswa yang mendapatkan reward.

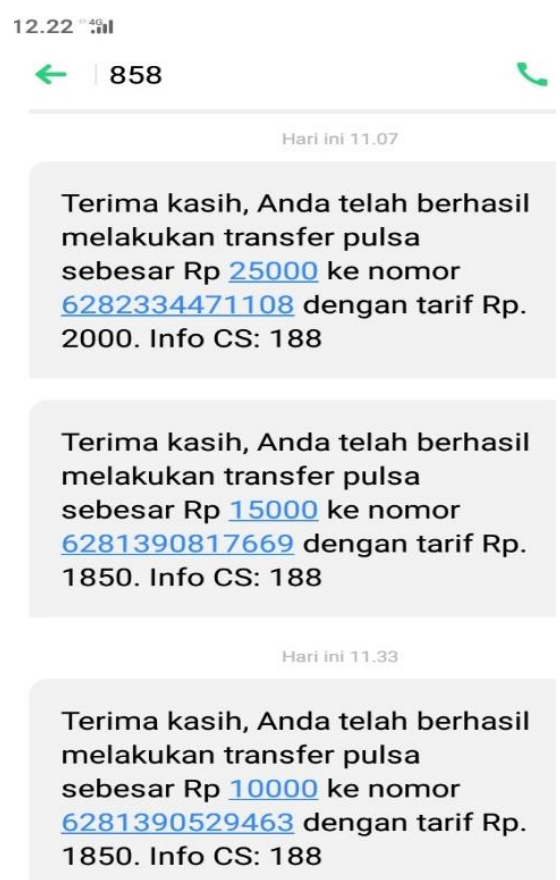

Gambar 5. Bukti transfer pulsa

Selanjutnya di hari kedua atau hari terakhir, kegiatan dikhususkan untuk pelatihan pengenalan dan pembelajaran Office 365 pada para guru. Berhubung jumlah peserta dari guru yang terdaftar sebanyak 70 orang guru, pelatihan hari kedua ini dilakukan di dua (2) laboratorium MAN 1 Semarang. Materi yang disampaikan juga sama dengan materi untuk siswa, yaitu one note, sway, dan team. Tampak pada Gambar 6. 


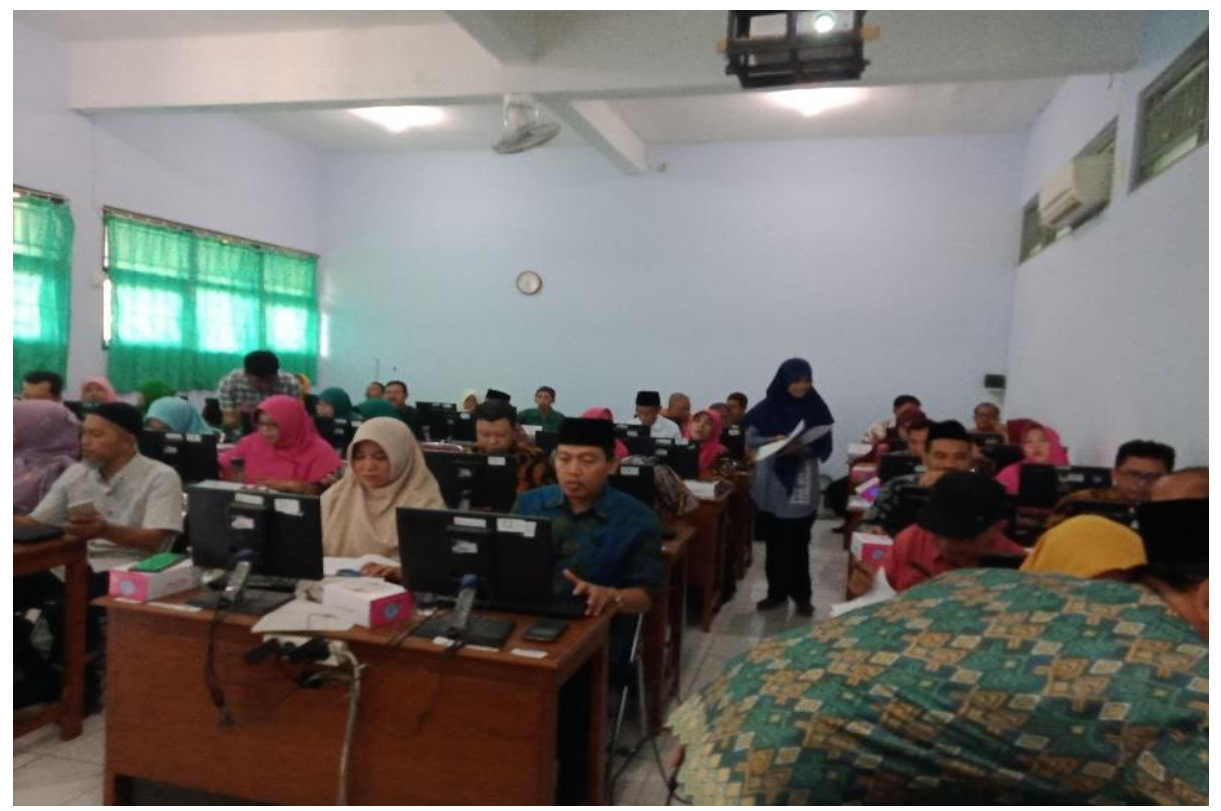

Gambar 6.Pelatihan hari kedua peserta guru-guru

\section{Luaran Yang Dicapai}

Sebagai indikator luaran yang dicapai dari kegiatan ini, tim pengabdian selain memberi tugas juga menyebarkan kuesioner sebagai pre test dan post test (lampiran). Dari hasil sebar kuesioner ini, tim pengabdian akan mengolah data yang ada untuk mengetahui secara pasti tingkat keberhasilan dari kegiatan pelatihan ini dari meningkatnya kemampuan peserta pelatihan dalam memahami dan mengoperasikan Microsoft Office 365.

Tabel 1. Hasil Kuesioner Siswa

\begin{tabular}{clccccc}
\hline \multirow{2}{*}{ NO } & \multicolumn{1}{c}{ NAMA SISWA } & \multicolumn{2}{c}{ Tes Awal } & \multicolumn{2}{c}{ Tes Akhir } \\
\cline { 3 - 6 } & & Benar & Salah & Benar & Salah \\
\hline 1 & Agvian Syahid Perdana & 4 & 6 & 10 & 0 \\
2 & Alfi Amaliyatus Sholihah & 6 & 4 & 9 & 1 \\
3 & Anfik Fauzi Masykuri & 5 & 5 & 10 & 0 \\
4 & Anisa Mayada Nuraini & 1 & 9 & 7 & 3 \\
5 & Anzikra Mozarellita Romadhona & 2 & 8 & 7 & 3 \\
6 & Ardiansah Fatkhur Rizqi & 7 & 3 & 10 & 0 \\
7 & Azalea Kirana Nurul Fadhillah & 5 & 5 & 9 & 1 \\
8 & Dean Muhammad Daffa Karim & 4 & 6 & 7 & 3 \\
9 & Dhafin Fajri Ramadhani & 0 & 10 & 5 & 5 \\
10 & Difanty Himatul A`la & 1 & 9 & 8 & 2 \\
11 & Dwi Rahayu Ningtyas & 5 & 5 & 7 & 3 \\
12 & Eka Intansari & 6 & 4 & 7 & 3 \\
13 & Galih Wahyu Satrio & 6 & 4 & 8 & 2 \\
14 & Intan Maulana & 7 & 3 & 10 & 0 \\
15 & Juliana Aisyah & 5 & 5 & 7 & 3 \\
16 & Laila Amelia & 6 & 4 & 8 & 2 \\
17 & Lailatun Nafis & 7 & 3 & 8 & 2 \\
18 & Luthfi Choirun Nisa & 8 & 2 & 7 & 3 \\
19 & Luthfi Puji Rahmawati & 5 & 5 & 8 & 2 \\
20 & Maulana Ihsyan Azwar & 5 & 5 & 6 & 4
\end{tabular}




\begin{tabular}{llcccc}
\hline \multirow{2}{*}{ NO } & \multicolumn{1}{c}{ NAMA SISWA } & \multicolumn{2}{c}{ Tes Awal } & \multicolumn{2}{c}{ Tes Akhir } \\
\cline { 3 - 6 } & & Benar & Salah & Benar & Salah \\
\hline 21 & Mila Kharisatul Aulia & 3 & 6 & 8 & 2 \\
22 & Mutiaraningsih & 2 & 7 & 9 & 1 \\
23 & Nabila Putri & 7 & 3 & 8 & 2 \\
24 & Naila Tohiroh & 4 & 6 & 7 & 3 \\
25 & Najma Raina & 5 & 5 & 7 & 3 \\
26 & Najma Zeta Zain & 5 & 5 & 9 & 1 \\
27 & Nandana Athila Nafi & 6 & 4 & 8 & 2 \\
28 & Nazula Hida Maghrisa & 5 & 5 & 8 & 2 \\
29 & Nova Melinda Ayu Permata Sari & & Tidak Hadir & \\
30 & Octavia Wijayanti & 3 & 7 & 6 & 4 \\
31 & Pradipta Setiaji & 3 & 7 & 6 & 4 \\
32 & Rika Safitri & 6 & 4 & 8 & 2 \\
33 & Salma Labibah Iskandar & 3 & 7 & 9 & 1 \\
34 & Salsabila Farid Putri Abela & 5 & 5 & 10 & 0 \\
35 & Siti Rohmania & 4 & 6 & 8 & 2 \\
36 & Syarifatul Muhajannah & 3 & 7 & 7 & 3 \\
37 & Vioni Amelia Arifiana & 2 & 8 & 6 & 4 \\
38 & Zuhdi Adi Winata & & &
\end{tabular}

$\square$ Peningkatan

Dari Tabel 1. Di dapatkan sebanyak 35 siswa dari 37 siswa peserta mengalami peningkatan pemahaman tentang aplikasi one note, sway, dan team dari Microsoft Office 365, atau sekitar $(35 / 27 * 100 \%)=94,5 \%$ siswa yang mengalami peningkatan pengetahuan, $(1 / 37$ $* 100 \%)=2,75 \%$ siswa masih memiliki pemahaman seperti sebelum kegiatan, serta $(1 / 37 *$ $100 \%)=2,75 \%$ siswa yang mengalami penurunan pemahaman setelah mengikuti kegiatan pelatihan.

Luaran lain yang telah dicapai oleh tim pengabdian adalah melakukan publikasi kegiatan di media online dan surat kabar antara lain : halosemarang.id, suarabaru.id, ayosemarang.com, surat kabar Suara Merdeka, dan channel you tube : https://www.youtube.com/watch?v=hnFfRcgi39g

Pada Gambar 7 tampak salah satu publikasi kegiatan yang telah terbit di harian surat kabar Suara Merdeka. 


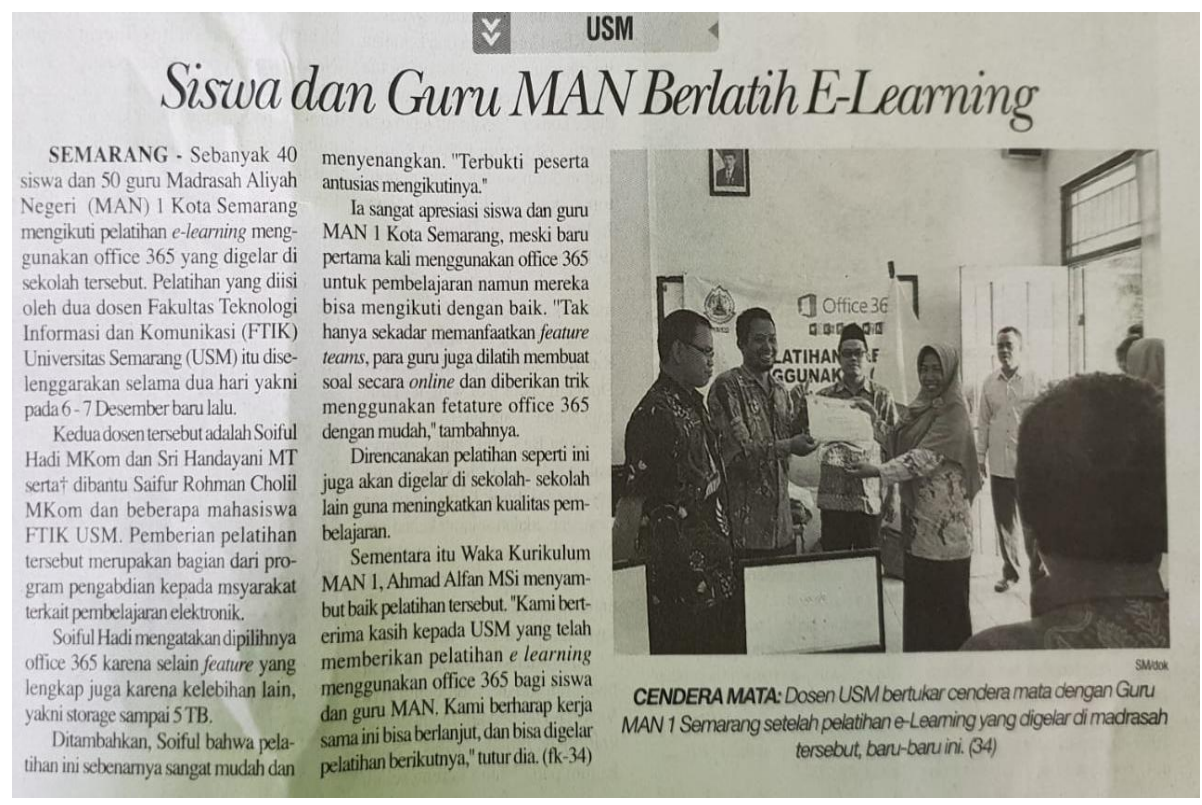

Gambar 7 Publikasi kegiatan di Suara Merdeka

Secara keseluruhan kegiatan Pengabdian Kepada Masyarakat di MAN 1 Semarang berlangsung dengan lancar, dan berakhir dengan pemberian cindera mata dari tim Pengabdian FTIK USM kepada Waka Kurikulum MAN 1 Semarang, Bpk.Ahmad Alfian M.Si. Acara pelatihan hari pertama dan kedua selalu diakhiri dengan foto bersama, tampak pada gambar 8 . Foto bersama tim pengabdian dengan siswa sebagai peserta pelatihan. Sementara pada gambar 9. foto bersama tim pengabdian dengan guru sebagai peserta pelatihan

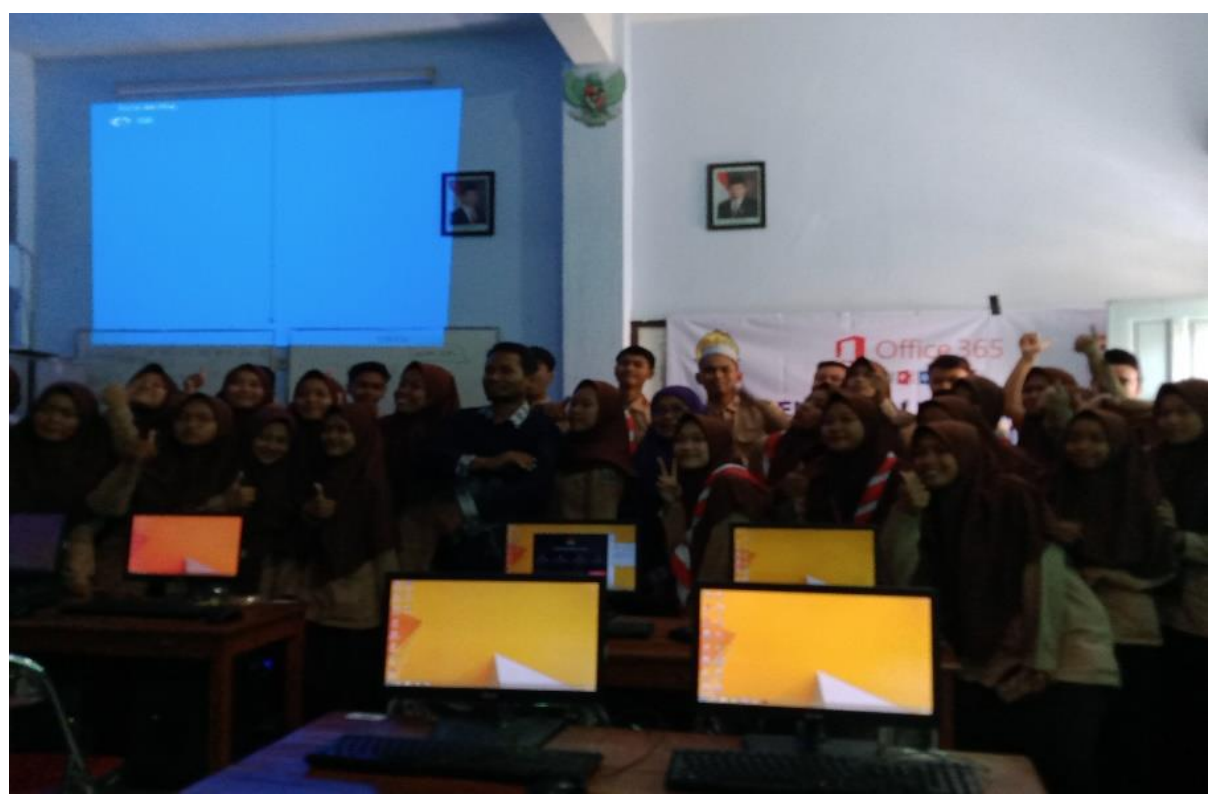

Gambar 8. Foto tim pengabdian dengan peserta siswa-siswa 


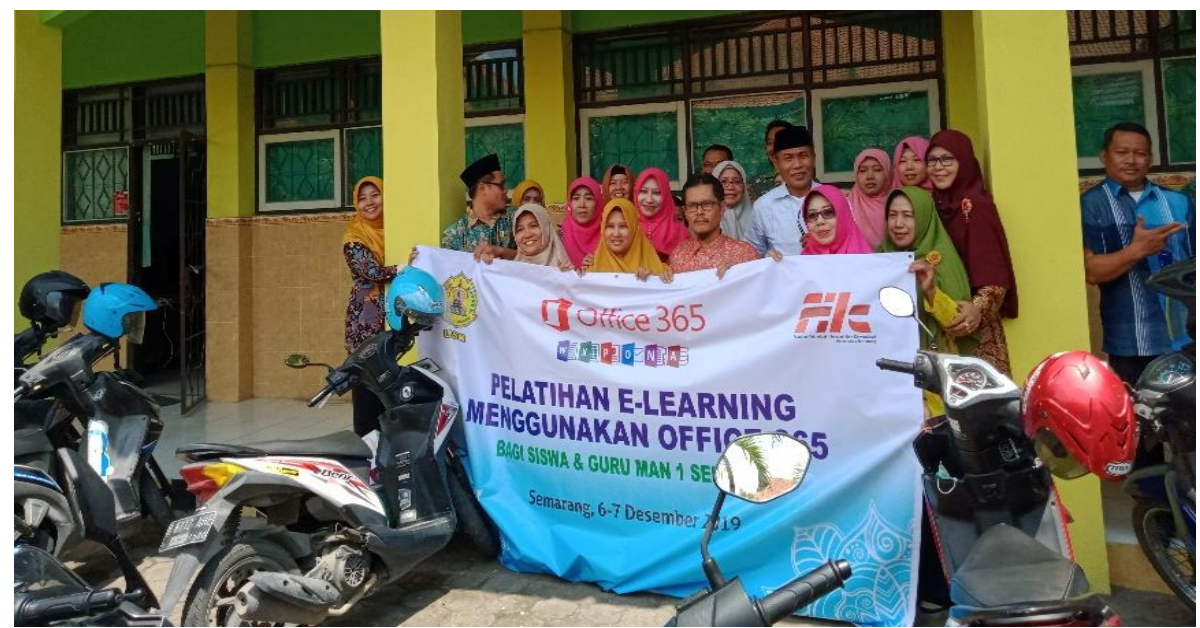

Gambar 9. Foto tim pengabdian dengan peserta guru-guru

\section{SIMPULAN}

Simpulan yang dapat diperoleh dari kegiatan pengabdian dengan judul Pengenalan dan Pembelajaran Microsoft Office Bagi Guru dan Siswa Madrasah Aliyah Negeri (MAN) 1 Semarang adalah:

1. Peserta pelatihan hari pertama diikuti oleh 37 orang siswa kelas XI IPA MAN 1 Semarang, dimana setelah dilakukan pelatihan diperoleh sekitar 94,5\% siswa yang mengikuti kegiatan pelatihan ini memperoleh peningkatan pemahaman dan peningkatan kemampuan mengoperasikan Microsoft Office 365.

2. Peserta pelatihan hari kedua diikuti oleh 62 orang guru MAN 1 Semarang, dimana seluruh peserta di hari kedua ini sangat bersemangat dalam mengikuti kegiatan pelatihan, selain karena memperoleh account Office 365 gratis dari USM, para peserta sangat berharap banyak agar aplikasi yang diperkenalkan dari Office 365 bukan hanya tentang one note, sway, dan team saja

\section{UCAPAN TERIMAKASIH}

Ucapan Terima Kasih dihaturkan untuk:

1. Iswoyo, S.Pt., M.P selaku Ketua Lembaga Penelitian dan Pengabdian Kepada Masyarakat (LPPM) USM.

2. Ahmad Alfan, M.Si selaku Wakil Kepala (Waka) Kurikulum MAN 1 Semarang.

3. Instruktur pendamping dari UPT Puskom USM : Saifur Rohman Cholil, Badru, dan Rian. 
4. Mahasiswa Program Studi Teknik Informatika angkatan 2016 kelas pagi yang telah membantu selama kegiatan : Ryan Pradana, Asni Alviana, Anggi Lailatul Hasanah, dan Indriana Novitasari.

\section{DAFTAR PUSTAKA}

Aribowo, E. K. (2017c). Microsoft OneDrive: Media Penyimpanan Virtual Lintas Platform. Tutorial. Diambil dari https://osf.io/preprints/inarxiv/mah7g/

Aribowo, E. K. (2017d). Sway: Cara Baru Menyajikan Presentasi dengan Multikonten (Gambar, Suara,7 Tautan, dan Video). Tutorial. Diambil dari https://osf.io/preprints/inarxiv/g2tb

Ferdiana, R., Eka, R., \& Fauzan, I. (2013). Petunjuk Praktis Microsoft Office 365 bagi Institusi Pendidikan dan Organisasi. Yogyakarta: Lulu Publisher.

Institute Technology Bandung (2015). Panduan Penggunaan Akun Microsoft Office 365

Microsoft Org (2018) Microsoft Office 365 Education Free and Legal

Ridi Terdanu, Randi Eka, Ibnu Fauzi (2018) Petunjuk Praktis Microsoft Office 365 Bagi Institusi Pendidikan, Microsoft Innovation Centre Yogyakarta 